\title{
CREATIVITY, INTERDISCIPLINARY EDUCATION AND THE USE OF TECHNOLOGY - CONDITIONS FOR A MODERN EDUCATION
}

CREATIVITATEA, ÎNVĂTAREA INTERDISCIPLINARĂ ŞI FOLOSIREA TEHNOLOGIEI - CONDIŢII PENTRU UN ÎNVĂŢĂMÂNT MODERN

\section{Adina MIHAI (CĂLUGĂRU)}

Journal of Pedagogy, 2019 (1), 93 - 103

https://doi.org/10.26755/RevPed/2019.1/93

The online version of this article can be found at: http://revped.ise.ro/category/2019-en/

\section{(C) $(1 \otimes 0$}

This work is licensed under the Creative Commons Attribution-NonCommercial-ShareAlike 4.0 International License. 94042, USA.

Published by:

\section{InStitutul de șTințe Ale eduCAȚIEI}

http://www.ise.ro/

Further information about Revista de Pedagogie - Journal of Pedagogy can be found at:

Editorial Policy: http://revped.ise.ro/editorial-policy/

Author Guidelines: http://revped.ise.ro/the-writer-guide-2/ 


\title{
CREATIVITY, INTERDISCIPLINARY EDUCATION AND THE USE OF TECHNOLOGY - CONDITIONS FOR A MODERN EDUCATION
}

\author{
Adina Mihai (Călugăru)* \\ Faculty of Psychology and Educational Sciences, \\ Bucharest, Romania \\ andinaro@yahoo.com
}

\begin{abstract}
The teacher can develop the students' creativity through different strategies, and it is up to him/her that the lessons should be attractive, interesting and lead on the one hand to a good collaboration among students, and on the other hand, to a good collaboration among the teacher and his/her students. Interdisciplinary teaching appears to be a necessity to overcome the artificial boundaries among disciplines and to correlate their contents, and the use of technology within classes helps to improve the educational process by seeking knowledge and skills that enable the student to adapt to the requirements of society, which are in constant evolution. The use of technology favours the teaching process through the following features: through multidisciplinary activities, by allowing access to non-school educational resources, by using images, sounds that facilitate the understanding of some abstract concepts, through the ability of searching for sources of information that stimulate curiosity, through the possibility of practicing for the formation of skills, through collaborative interactions in solving some projects.

In order to achieve a modern, but also highly qualitative education, the teacher has to combine classical and modern methods correctly, to be creative, and the technology should be used with measure and at the right time. The key to the successful use of informational and communicational technology is not the choice of tools or programs, but the ability of the teacher to plan, create and implement a creative and effective activity.
\end{abstract}

Keywords: collaboration, creativity, interdisciplinary teaching.

* PhD., Faculty of Psychology and Educational Sciences, University of Bucharest, Romania. 


\section{Rezumat}

Profesorul poate dezvolta creativitatea elevilor prin diferite strategii si de el depinde ca lec iile să fie atractive, interesante şi să conducă pe de o parte la o colaborare bună între elevi, iar pe de altă parte între profesor şi elevii săi. Învă area interdisciplinară apare ca o necesitate pentru a depăşi grani ele artificiale între discipline şi pentru a corela con inuturile acestora, iar folosirea tehnologiei în cadrul orelor ajută la îmbunătă irea procesului instructiv-educativ, urmărind achizi ionarea unor cunoştin e şi formarea unor deprinderi, care să permită elevului să se adapteze cerin elor societă ii, aflate într-o permanentă evolu ie.

Utilizarea tehnologiei favorizează procesul de învă are prin următoarele trăsături: prin activită ile multidisciplinare, prin faptul că permite accesul la resurse educa ionale din afara şcolii, prin recurgerea la imagini, sunete care facilitează in elegerea unor concepte abstracte, prin capacitatea de căutare a surselor de informa ii ce stimulează curiozitatea, prin posibilitatea exersării unor deprinderi, prin interac iunile colaborative în rezolvarea unor proiecte.

Pentru a realiza un învă ământ modern, dar şi de calitate, profesorul trebuie să îmbine corect metodele clasice cu cele moderne, să fie creativ, iar tehnologia să fie folosită cu măsură şi la momentul potrivit. Cheia pentru utilizarea cu succes a tehnologiei informa iei şi a comunica iilor nu constă în alegerea unor instrumente sau programe, ci în capacitatea profesorului de a planifica, a crea şi implementa o activitate care să fie creativă şi eficientă.

Cuvinte cheie: colaborare, creativitate, învă are interdisciplinară.

\section{The use of technology in gymnasium education}

The emergence of technology has produced important changes in the educational environment because teachers have improved their teaching by integrating the computer using both its facilities and web tools to create a more creative teaching approach, being in tune with the concerns of the current generation for which technology has become a "modus vivendi". According to the Annex to the Recommendation of the European Parliament and the European Council from 18 December 2006 concerning key competences for lifelong learning, one of the eight key competences is the digital competence. One of the objectives of the European Union, established since 2000 , is to make it the most competitive knowledge-based economy in the world, and the integration of ICT tools into the educational process is an important step in achieving this goal. 
"The digital curriculum and the network applications will transform the teaching-learning-evaluation process. The School of the Future will certainly be a cybernetics school, an interdisciplinary 'living' computer lab that will early prepare the students to become problem solvers, new creators and capable of making optimal decisions to address increasingly to the unusual and novel situations of the present and future social life" (Oprea, 2006). Digital classes will bring together students from several continents, and in the classroom and digital school the teacher's roles are diversified. Over time, the teacher has benefited from society's respect for his/her knowledge, being considered "the source of wisdom". Now, a teacher can no longer compete with the information on the internet, which can be written by the world's largest experts in a particular field. Students' technological knowledge often exceeds that of teachers, so new pedagogical skills are needed to gain students' respect. Teachers' contribution is no longer to provide information, but to help the student find, select, identify reliable sources, and teach him how to use them.

Learning in a virtual environment is based on self-learning and co-operative learning theories, and the modern teacher becomes facilitator, encouraging debate, initiative, creativity, teamwork. Students and activities are at the centre of attention. They can work together even if they are in different places, share information and resources, and work on the same document. Digital systems can make teaching work more efficient, creating new ways to promote personal initiative, critical skills and social interaction. The pupil can acquire the values and attitudes of an entrepreneurial citizen who works in a team that manages to interpret reality, to be tolerant with those students who have different points of view.

Everett M. Rogers in the paper: "Diffusion of innovation" identifies five steps concerning the use of computers in class by the teacher: 1) the dissonance phase - the teacher does not use the technology, instead, the student uses it but guided by others. The student has a computer at home and takes lessons in private; 2 ) the convincing phase - the teacher starts to provide new information through the computer, and the technology is just a support for traditional methods; 3 ) the decision stage - the teacher accepts to adopt technology and begins to learn how to use it ("technical changes") - the teacher uses CDsCD sites, videos, attends courses to improve his 
skills; 4) the implementation stage: the teacher goes from computer familiarity to systematic use and considers it a useful tool in the teaching-learning-evaluation process. The students use the computer to present their projects, make power-point presentations, make websites, etc; 5) confirmation stage: the teacher invents new computer-aided applications to support students, communicates and collaborates with other teachers to streamline the use of technology in school.

A survey conducted in several schools in America last year, involving interviewing 700 teachers, showed that most teachers use technology to improve the teaching process $(94.9 \%)$, others $81.3 \%$ to introduce a subject, and $77.4 \%$ to demonstrate a concept. The most used multimedia tools in the class were: Power Point and YouTube.

With regard to the use of web-based tools by students, $40 \%$ of them, aged between ten and eighteen years old, confessed in a poll conducted in Spain that they built a blog, a website, thus passing from the consumer to the content creator. Students know more about the technological tools that define the reality we live in.

On the other hand, numerous studies have highlighted the significant impact of using technology on school performance. The students who used technology for learning had better cognitive and affective outcomes than those who did not use the technology. It has been highlighted that ICT has a positive impact on the performing students and less on those with a lower performance. Parents consider notebooks to have a positive effect on students' IT skills (Mitchell Institute, 2004).

One of the international evaluations, TIMSS (Trends in International Mathematics and Science Study) in 2011, at the 4th grade, also pursued interest in the use of ICT in the educational process, and the results revealed differences in the percentage of teachers using computers in the process of teaching, among the European countries. In Italy, Serbia, Hungary, Poland, Spain and Romania, half of the teachers use the computer in the teaching process, being considered an average level. The second level was found to be high in terms of computer use, as about two-thirds of teachers use the computer encompassing the following countries: Czech Republic, Germany, 
Russia and Croatia. Countries where almost all teachers use the computer are: Finland, Ireland, Denmark, Lithuania, Norway, Portugal, Slovenia, Sweden, and the United Kingdom of Great Britain and Northern Ireland have the highest percentage of teachers using technology in teaching.

The computer is an instrument in student education. Through computer lessons and educational games, teachers increase students' interest in school because these things stimulate their imagination. In fact, using technology is not a revolution in education, but it brings renewal to education, an evolution that leads to profound changes.

\section{Digital instruments used in gymnasium}

The means of education used by teachers have changed over time and the demand for the revolution of education through the introduction of new technologies is constantly increasing. Also, the enthusiasm for these modern means is high.

Digital textbooks were introduced at both primary and secondary levels. They can be accessed free of charge by teachers, students and parents. Their use represents multiple advantages through the functions they perform. Among these, they recall: the training function, favoring a rapid communication of information that can be rapidly received by students, the motivation function of learning, because the visual and auditory messages have the role of motivating the student; the function of guiding professional interests, helping students get information about certain professions (Oprea, 2006).

Gymnasium students may be involved, given the advanced knowledge they have to create content in the form of videos. An experiment of this kind was carried out in Spain, students having as a topic the creation of a video that should include information about a particular subject in the sciences. When pupils presented the videos in the classroom, they noticed the intense discussion about the content, being a useful reflection moment (Souza \& Ferreira, 2008). Students have come to understand the information, having a critical attitude, too. There are certain points of the technique used in 
television that can be used in education too, such as "factic" or contact function, which aims to establish and maintain contact between interlocutors. The teaching-learning process can achieve its objectives only if it succeeds in determining changes in the recipient of the education, and the school should work to produce content without limiting itself only to a field, and through interdisciplinary learning the artificial boundaries between disciplines can be overcome to correlate their contents. Digital textbooks also serve as aesthetic function, the students having access to the artwork and life lessons.

We can also highlight the ergonomic function of digital textbooks because their use involves saving time in the transmission of information and facilitating the development of activities that are suited to students' age peculiarities. Of course, teachers cannot limit only to the use of digital textbooks in class, because these digital textbooks cannot perform the experimental investigation and practical skills training.

The interactive whiteboard is another very useful tool in teaching because the lessons made by the teacher can be presented to the students in an attractive way. Any application can be activated and controlled simply by touching the board. Observations can be made on the accessed document and the information can be saved and sent to students. In science classes, at Geography, for example, this tool can find its usefulness because phenomena and geographic processes can be viewed and analysed, and students can understand them much easier. The evaluation process also has a considerable improvement, "by increasing its objectivity and the ability to personalize the evaluation". Evaluation can be done by applying grid tests, interactive tests, or handouts that students can work in digital format.

Google Docs contributes to collaborative learning among students by using the programs: "Documents", "Spreadsheets" or "Presentation".

Students are increasingly involved in group activities with interdisciplinary approaches. For example, in the Romanian language and literature discipline students can create a travel journal and, for their realization, they will capitalize both geography information, draw sketches and maps, and ultimately exercise their literary talent by writing the resulting ideas and impressions after the trip. Then the information obtained can be posted on 
a blog to be read by other colleagues or to be debated by other interested parties. By using new technologies and applying them to the teaching process, the role of the teacher changes as he/she becomes a facilitator in online communities.

A useful communication tool available to teachers is the eTwinning platform, the main purpose of which is to facilitate communication and collaboration between pupils, as well as between teachers from different countries in the European Union. Through communication, facilitated by this platform, various educational products can be created and students can engage in common curricular activities.

Two digital tools that can be used in the classroom both to achieve cognitive goals and also to verify students' knowledge in a creative way, are Kahoot and Storybird.

The Kahoot application turns learning and evaluation into a play and can be used at any age. Students can participate individually or in a team, and verification of content assimilation becomes an easy procedure for both students and teachers. A positive aspect is the diminution of stress associated with the evaluation, and a limitation is that the real skills of the students, corresponding to higher taxonomic levels, cannot be assessed.

Storybird is an application that allows the creation of illustrated stories using the resources available online. Stories can also be published online. It is an easy-to-use digital tool for subjects in the Language and Communication Curriculum, but also in other disciplines: history, biology, geography, and management.

Educreations is an application for creating mini-lessons. Teachers can create videos to explain their concepts to students and ask them to collaborate on the content.

Glogster is another application that involves using images, videos, music and photos to create multimedia pages. It is possible to create multimedia interactive posters, which can then be shared, multimedia portfolios and cross-curricular activities. 
Bubbl.us is an online brainstorming application. Conceptual maps can be created to improve creative thinking. An application that encourages creativity is ThinkLing, an interactive media platform that can create interactive images, maps, posters, and albums.

Educational software is an important resource that can be used in teaching/ learning activities, turning learners into active participants in learning. The main objective of using educational software is to increase interaction with students who "can perform various didactic tasks, adapted and integrated effectively in learning situations." (Buxarrais Estrada, 2011). The software is attractive, suggestive, being coherent as image and text and is adapted to the competencies specified in the curriculum. An important and very attractive resource in Geography classes is Google Earth, which allows for variable-scale visualization of territorial reality. Students can watch "satellite images", digital maps. By using this application, students are actively involved in the teaching-learning process, their visual memory, new desire, their curiosity is being stimulated, allowing the objective assessment of the results and progress they have achieved. In this context, it can surely be emerged that creative teachers determine the momentum of students' creativity without any special effort. "The secret lies in transferring the set of values favorable to creativity from the mentor to the disciple, a phenomenon followed by self-development and self-formation." (Dulamă, 2008). The good teacher will allow the student to take intellectual risks, make unusual associations, be an active and creative participant in their own training, know how to collect information from as many sources as possible. That is why the school has to keep up with the new and use as many resources as possible, updating the methods, but also the knowledge. In terms of developing the student's creativity it is very important to stimulate his/her personal effort to make his own contributions, to be original, creative, and inventive.

The motivating, interesting activities that are in accordance with the student's interests and desires will stimulate his/ her personal effort, his/her tendency to bring an original contribution, and the activity of the teacher does not cease once the lesson is completed and through the modern means of communication can go beyond its framework. 
The use of teaching moments in educational software helps to stimulate student creativity in a $50 \%$ proportion, and the introduction of a power point helps to better understand the studied concepts. The method of building lessons with the help of technology helps to increase the efficiency of the lesson, both for the student and for the teacher. Even in Math classes in gymnasium, students' uncertainties can be resolved by using technology, as the teacher can make students "visualize" Math problems using videos. Many students fail to translate to the level of imagination the requirements of problems, and when using classical methods of working on a blackboard fails, the use of a program dedicated to computer-aided design or the use of animated materials makes it possible to understand abstract concepts.

The lesson of teaching-learning-using which uses these digital techniques becomes "an adventure of knowledge" in which the student actively participates, asking questions, clarifying his possible doubts, and eventually discovering plausible solutions. The role of the teacher is more of encouraging and guiding, and the student who is involved both in the teaching, learning and evaluation process acquires a self-discipline of work. It is the teacher the one who can develop students' creativity through different strategies, it depends on him/her that the lessons should be attractive, interesting and lead, on the one hand, to a good collaboration among students, and on the other hand, among the teacher and his/her students. Mark Goddard asserted that teachers are responsible for the success of their students. The teacher influences the active and creative behavior of the student, and cooperative learning also ensures the development of optimal relationships.

In the actual context, the teacher must be a good organizer of learning situations in which he demonstrates a lot of creativity and should be a link between student and society, helping him to correlate the information obtained in various disciplines.

Beyond the inherent benefits of using technology, the student does not have to become an uncritical user who knows how to exploit the computer. It should be borne in mind that in some subjects human involvement is needed to be more emotional, so that emotional desires, and team work should be valued. Although some specialists consider that teaching based on the use of technology and the Internet is too static, the use of these tools opens up 
multiple training opportunities in various fields and offers the teacher the opportunity to create interactive, creative, and accessible lessons, but also to the student to become a creator of content.

I believe that student-centered education cannot ignore modern teaching methods, involving the use of interactive whiteboard, educational software, digital textbooks, the Internet, and various applications that can make the contents of different disciplines more accessible. The teacher's role is to correctly combine traditional and modern methods, to plan activities in order to surprise students.

\section{References}

- Buxarrais Estrada, M. R., \& Evaristo, O. (2011). El impacto de las nuevas tecnologias en la educacion en valores del siglo XXI. Sinectica, 37(1).

- Constantin, L.-V., \& Dinică, L. (2006). Eficien a utilizării TIC în procesul instructiv educativ. Conferin a Na ională de învă ământ virtual, edi ia a IV-a.

- Dulamă, M. E. (2008). Metodologii didactice activizante. Cluj-Napoca: Editura Clusium.

- Goddard, M. (2002). What do we do with these computers? Reflections on technology in the classroom. Journal of Research on Technology in education, 35(1), 19-26. https://doi.org/10.1080/15391523.2002.10782367.

- Higgins, K., \& BuShell, S. (2018). The effects on the student-teacher relationship in a one-to-one technology classroom. Education and Information Technologies, 23(3), 1069-1089. https://doi.org/10.1007/s10639-017-9648-4.

- Loague, A., Caldwell, N., \& Balam, E. (2018). Professors 2 attitudes and perceptions about technology use in the classroom. Alabama Journal of Educational Leadership, (5), 1-11.

- Marinescu, M. (2007). Tendin e şi orientări în didactica modernă. Bucureşti: Editura Didactică şi Pedagogică.

- Martin, F., \& Carr, M. (2015). An exploratory study on k-12 teacher' use of technology and multimedia in the classroom. Journal of Educational Technology, 12(1), 7-14.

https://doi.org/10.26634/jet.12.1.3431.

- Oprea, C. L. (2006). Strategii didactice interactive: repere teoretice şi practice. Bucureşti: Editura Didactică şi Pedagogică.

- Souza, I. K., \& Ferreira do Amaral. (2008). The use of digital video in class: a 
pedagogical proposition. Comunicar, 16(31), 457-461.

https://doi.org/10.3916/c31-2008-03-035.

- Vescan, S. I. (2010). Dinamizarea procesului de predare-învă are-evaluare cu ajutorul resurselor TIC în ora de geografie. Cluj-Napoca: Colegiul Economic „Iulian Pop”.

- Warwick M. L. P., Rasmussen, I., Ludvigsen, S., \& Cook, V. Classroom dialogue and digital technologies: a scoping review. Education and Information Technologies, 23(5), 1995-2028. https://doi.org/10.1007/s10639-018-9701-y.

The online version of this article can be found at: http://revped.ise.ro/category/2019-en/

\section{(Cc) $\mathrm{BY}-\mathrm{NC}-\mathrm{SA}$}

This work is licensed under the Creative Commons Attribution-NonCommercial-ShareAlike 4.0 International License.

To view a copy of this license, visit http://creativecommons.org/licenses/by-nc-sa/4.0/ or send a letter to Creative Commons, PO Box 1866, Mountain View, CA 94042, USA.
Versiunea online a acestui articol poate fi găsită la: http://revped.ise.ro/category/2019-ro/

\section{(CC) $\mathrm{BY}-\mathrm{NC}-\mathrm{SA}$}

Această lucrare este licen iată sub Creative Commons Attribution-NonCommercial-ShareAlike 4.0 International License.

Pentru a vedea o copie a acestei licen e, vizita $i$ http://creativecommons.org/licenses/by-nc-sa/4.0/ sau trimite i o scrisoare către Creative Commons, PO Box 1866, Mountain View, CA 94042, SUA. 